\title{
ANALISIS KUALITAS PELET LELE BIO SLURRY DESA ARGOSARI KABUPATEN MALANG
}

\section{Bio Slurry Catfish Feed Analysis Quality Study In Argosari Village Malang District}

\author{
Nestya Hariyoko ${ }^{1 *}$, Elok Zubaidah ${ }^{1}$, Dewi Maya Maharani \\ 1) Jurusan Teknologi Hasil Pertanian, FTP Universitas Brawijaya Malang \\ 2) Jurusan Keteknikan Pertanian, FTP Universitas Brawijaya Malang \\ Jl. Veteran, Malang 65145 \\ Penulis korespondensi, email: nestyahariyoko@student.ub.ac.id
}

\begin{abstract}
ABSTRAK
Desa Argosari memiliki 60 instalasi biogas yang menghasilkan limbah bio slurry sekitar 300-500 kg/hari. Tujuan penelitian ini adalah mendapatkan komposisi terbaik untuk pembuatan pakan ikan lele dan mengetahui penerapan dan pengaplikasian berbahan dasar Bio Slurry untuk pembuatan pupuk (cair dan padat). Metode yang digunakan dalam penelitian ini adalah analisis deskriptif dan analisis perlakuan terbaik menggunakan metode Multiple attribute Zeleny. Hasil uji proksimat untuk P1 adalah kadar protein $18.93 \%$, kadar lemak $2.16 \%$, kadar abu $21.42 \%$, kadar serat kasar $15.50 \%$, kadar air $9.50 \%$, dan daya apung selama 54.50 menit, P2 adalah kadar protein $15.58 \%$, kadar lemak $2.11 \%$, kadar abu $23.17 \%$, kadar serat kasar $17.00 \%$, kadar air 9.40\%, dan daya apung selama 57.25 menit, P3 adalah kadar protein $12.41 \%$, kadar lemak $1.90 \%$, kadar abu $25.75 \%$, kadar serat kasar $20.00 \%$, kadar air $8.60 \%$, dan daya apung selama 62.25 menit.
\end{abstract}

Kata kunci: Bio Slurry, Pelet Lele, Pupuk

\section{ABSTRACT}

Argosari village has more than 60 of biogas installation that produced about $300-500$ $\mathrm{kg}$ bio slurry/day. The aims of this research are to get the best composition for catfish's feed and to know about the application of bioslurry for liquid or solid plants fertilizer. Methods used in this research is descriptive analysis and analysis of the best treatment used Multiple attribute Zeleny method. The result of proximate test shows that $P 1$ has $18.93 \%$ of protein content, $2.16 \%$ of fat content, $21.42 \%$ of ashes, $15.50 \%$ of crude fiber, $9.50 \%$ of water content and has 54.50 minutes of buoyancy. $P 2$ has $15.585 \%$ of protein content, $2.11 \%$ of fat content, $23.17 \%$ of ashes, $17 \%$ of crude fiber, $9.40 \%$ of water content and 57.25 minutes of buoyancy ability. P3 has $12.41 \%$ of protein content, $1.90 \%$ of fat content, $25.75 \%$ of ashes, $20 \%$ of crude fiber, $8.60 \%$ of water content and 62.25 minutes of buoyancy ability. The best treatment shown in (P1) treatment.

Keywords : Bio Slurry, Catfish Feed, Fertilizer

\section{PENDAHULUAN}

Desa Argosari merupakan salah satu desa yang terletak di kecamatan Jabung kabupaten Malang. Desa ini memiliki 272 kepala keluarga yang sebagian besar bermata pencaharian sebagai peternak sapi yakni sekitar $60 \%$ dari total penduduk. Desa Argosari termasuk salah satu wilayah konservasi lingkungan dalam pelestarian hutan dan perlindungan air bersih di Jawa Timur dan terkena program sanitasi biogas sejak 2004. Saat ini desa Argosari memiliki 60 instalasi biogas yang menghasilkan limbah bio slurry cukup banyak sekitar 300-500 kg setiap hari. Bio slurry merupakan limbah dari hasil pengolahan biogas. Bio 
slurry dihasilkan saat proses pengolahan anaerobik (tanpa udara/oksigen) atau fermentasi dimana $30-40 \%$ zat organik kotoran sapi diubah menjadi biogas (metana dan karbondioksida). Oleh karena itu, bio slurry dapat diolah menjadi beberapa produk seperti pelet ikan lele dumbo dan pupuk (cair dan padat).

Pelet ikan lele berbahan dasar bio slurry dapat dibuat dari slurry padat dengan campuran bahan lain untuk menambah protein. Bahan campuran untuk membuat pelet ikan lele diantaranya sisa jerohan ayam dan bekatul. Menurut Falahudin dkk. (2016), mengatakan bahwa suatu bahan yang dapat digunakan sebagai bahan baku pakan harus memenuhi persyaratan tertentu yaitu mempunyai nilai gizi tinggi, tersedia dalam jumlah melimpah, kontinuitas, dan secara ekonomi tidak menjadikan harga pakan tinggi. Syarat pakan lele dumbo (Clarias gariepinus) diatur dalam SNI 01-4087-2006 tentang pakan buatan untuk ikan lele dumbo (Clarias gariepinus) pada budidaya intensif. Oleh karena itu, berkaitan dengan hal tersebut penulis mengunakan bahan baku bio slurry dari limbah biogas untuk membuat beberapa produk diantaranya pelet ikan lele dumbo dan pupuk (cair dan padat). Pada penelitian ini akan dikaji formulasi pembuatan pelet ikan menggunakan metode deskriptif analisis pendekatan metode Zeleny untuk menentukan perlakuan terbaik dalam menentukan komposisi pembuatan pelet dengan bahan baku slurry biogas, dedak, tepung ikan, jerohan ayam, dan tepung tapioka.

\section{BAHAN DAN METODE}

\section{Bahan}

Bahan yang dibutuhkan dalam penelitian ini adalah bio slurry yang diambil di tempat penampungan slurry biogas desa Argosari, dedak padi, tepung ikan, jerohan ayam, $\mathrm{NaOH}$, $\mathrm{H}_{2} \mathrm{SO}_{4}$, Aquades.

Alat

Alat yang dibutuhkan pada penelitian ini antara lain: timbangan (Metler Toledo), alat titrasi, lemari asam, oven listrik, furnace (Thermolyne 47900), soxhlet, alat destruksi protein, destilasi protein (Büchi Destillation Unit K-350), pompa vacuum.

\section{Metode}

Penelitian ini menggunakan metode deskriptif analisis dengan pendekatan kuantitatif menggunakan metode Multiple Attribute (Zeleny). Pada penelitian ini digunakan tiga faktor seperti pada tabel dibawah ini:

Tabel 1. Faktor Penelitian yang Digunakan

\begin{tabular}{cl}
\hline Perlakuan & \multicolumn{1}{c}{ Keterangan } \\
\hline P1 & $\begin{array}{l}\text { Pelet ikan lele dengan komposisi bio slurry 25\%; tepung ikan 40\%; } \\
\text { dedak 10\%; jerohan ayam 20\%; dan tepung tapioka 5\%. }\end{array}$ \\
P2 & $\begin{array}{l}\text { Pelet ikan lele dengan komposisi bio slurry 30\%; tepung ikan 35\%; } \\
\text { dedak 10\%; jerohan ayam 20\%; dan tepung tapioka 5\%. }\end{array}$ \\
P3 & $\begin{array}{l}\text { Pelet ikan lele dengan komposisi bio slurry 35\%; tepung ikan 30\%; } \\
\text { dedak 10\%; jerohan ayam 20\%; dan tepung tapioka 5\%. }\end{array}$ \\
\hline
\end{tabular}

Pada penelitian ini dilakukan pengulangan pengujian sebanyak 2 kali. Tahap pertama penelitian adalah membuat pelet dengan perbandingan yang telah ditentukan. Pelet yang dihasilkan kemudian dianalisis kualitasnya berdasarkan analisis fisik, proksimat, dan lama pelet bio slurry mengapung. 
HASIL DAN PEMBAHASAN

\section{Analisis Fisik Pelet Bio Slurry}

Tabel 2. Perbandingan Fisik Pelet Bio Slurry Dan Pelet Lele Komersial

\begin{tabular}{lll}
\hline Parameter pelet & \multicolumn{1}{c}{ Bio slurry pelet } & Pelet ikan pabrikan (Nuraini, 2017) \\
\hline Bentuk & Silinder & Oval, Silinder \\
Tekstur & Padat Berongga 2-3 $\mathrm{mm}$ & Padat berongga 1-2 mm \\
Diameter Warna & Cokelat & Cokelat kekuningan \\
Aroma & Amis menyengat & Amis menyengat \\
\hline
\end{tabular}

Berdasarkan Tabel 2, pelet bio slurry memiliki kenampakan fisik yang serupa dengan pelet ikan pabrikan berdasarkan bentuk, tekstur, diameter, dan aroma. Pelet berbahan bio slurry memiliki warna yang lebih gelap dibandingkan pelet ikan pabrikan karena bio slurry yang dihasilkan pada proses fermentasi berwarna cokelat. Aroma pelet yang berasal dari bio slurry menyengat diakibatkan oleh pemberian jeroan ayam yang memiliki aroma yang khas sehingga pelet yang dihasilkan beraroma menyengat seperti pelet pabrikan. Menurut Saade dan Aslamyah (2009), pakan yang baik adalah pakan yang memiliki aroma khas yang disukai oleh kultivan. Pelet bio slurry memiliki tekstur yang padat karena adanya proses pengukusan (conditioning). Proses conditioning adalah proses pemanasan dengan uap air pada bahan yang ditujukan untuk gelatinisasi agar terjadi perekatan antar partikel bahan penyusun sehingga penampakan pelet menjadi kompak, durasinya mantap, tekstur dan kekerasannya bagus.

\section{Kadar Abu}

Berdasarkan penelitian yang telah dilakukan terhadap ketiga perlakuan, P1 memiliki kadar abu paling rendah yakni sebesar $21.415 \%$ kemudian P2 memiliki kadar abu $23.17 \%$ dan P3 memiliki kadar abu paling tinggi yakni 25.75\%. Namun, ketiga belum memenuhi standar SNI karena SNI maksimal yang dianjurkan adalah sebesar 13\%.

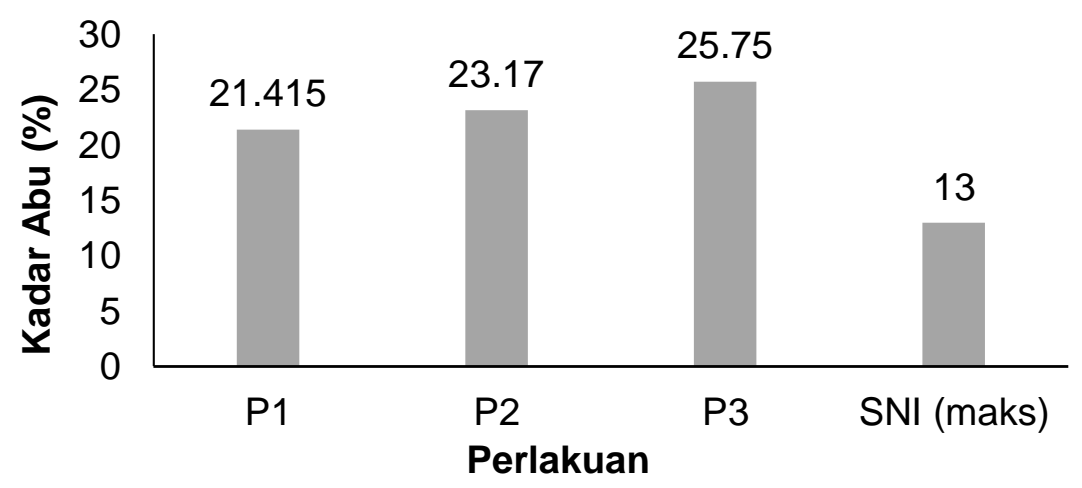

Gambar 1. Perbandingan Kadar Abu Pelet Bio Slurry (P1, P2, dan P3) dan Standar Nasional Indonesia 01-4087-2006.

Ketiga perlakuan memiliki kadar abu tinggi disebabkan dari bahan baku yang digunakan adalah Bio slurry. Menurut penelitian yang dilakukan Susanti, et al. (2016), kandungan bio slurry paling besar adalah mineral Kalium $(\mathrm{K})$ dan Phospor $(\mathrm{P})$ tersedia secara berurutan sebesar 570.310 ppm dan 1.034 .790 ppm dengan kriteria sangat tinggi dan bahanbahan lain seperti kandungan pasir sebesar $77.690 \%$, debu $17.9 \%$ dan liat $4.410 \%$. Adanya pasir, debu, liat, dan beberapa mineral yang memiliki titik didih yang tinggi dapat berpotensi terukur sebagai abu. Oleh karena itu, pelet ikan berbahan bio slurry memiliki kadar abu yang cukup tinggi. 


\section{Kadar Protein}

Berdasarkan hasil penelitian yang telah dilakukan terhadap ketiga perlakuan, perlakuan yang memiliki kadar protein paling tinggi yakni pada $\mathrm{P} 1$ yang memiliki rata-rata kandungan protein $18.93 \%$. Sedangkan, P2 memiliki kandungan protein sebesar $15.575 \%$. P3 memiliki kandungan protein paling rendah yakni sebesar $12.41 \%$. Namun, ketiga perlakuan tidak sesuai dengan standar SNI yang telah ditetapkan yakni protein minimal untuk pembesaran ikan lele sebesar 25\%. P1 memiliki kandungan protein paling tinggi karena komposisi pelet ikan yang digunakan $40 \%$ berasal dari tepung ikan yang merupakan sumber protein paling besar.

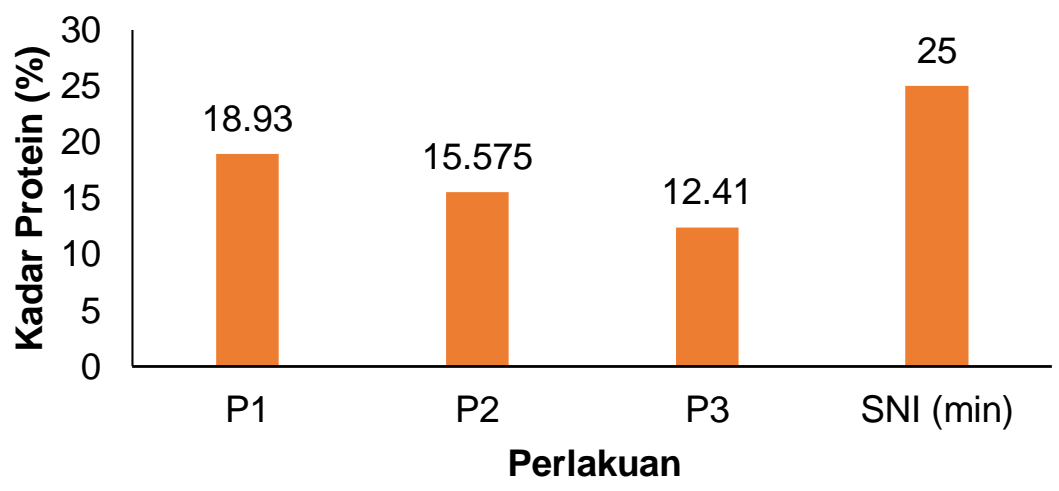

Gambar 2. Perbandingan Kadar Protein Pelet Bio Slurry (P1, P2, dan P3) dan Standar Nasional Indonesia 01-4087-2006.

Menurut Hariati (2010), menyatakan bahwa penggunaan dua atau lebih sumber protein dalam ransum akan lebih baik daripada satu sumber. Sedangkan, menurut Djuanda dalam Dani dkk. (2005), sebagian dari makanan yang dimakan oleh ikan berubah menjadi energi yang digunakan untuk aktivitas hidup dan sebagian keluar dari tubuh. Jadi, tidak semua protein makanan yang masuk kedalam tubuh ikan diubah manjadi daging. Pembentukan protein daging juga bergantung pada kemampuan fisiologis ikan. Menurut Marlitha (2013), peningkatan protein pakan tidak selalu menyebabkan peningkatan pertumbuhan pada ikan. Peningkatan protein pakan tanpa diikuti keseimbangan dengan sumber energi non protein akan menyebabkan protein digunakan sebagai sumber energi.

\section{Kadar Air}

Analisis yang dilakukan terhadap ketiga perlakuan merupakan analisis kadar air dengan metode oven secara gravimetri. Berdasarkan hasil analisis P1 memiliki rata-rata kadar air sebesar 9.5\%. Sementara itu, P2 memiliki kandungan air sebesar 9.4\% dan P3 memiliki kadar air sebesar $8.6 \%$. Ketiga perlakuan telah sesuai dengan standar SNI untuk pakan yang telah ditetapkan yakni maksimal $12 \%$. Kadar air bahan sangat berpengaruh terhadap aktivitas mikrobiologis yang dapat menyebabkan kerusakan produk selama pengangkutan dan penyimpanan.

Menurut Sahwan (2002), kadar air pakan sebaiknya tidak melebihi $10 \%$. Tingkat kekeringan pakan sangat menentukan daya tahan pakan karena apabila pakan buatan mengandung banyak air maka pakan yang dihasilkan akan menjadi lembab dan rentan untuk berjamur. Oleh karena itu, kualitas pakan yang dihasilkan akan menurun dan berbahaya terhadap ikan. 


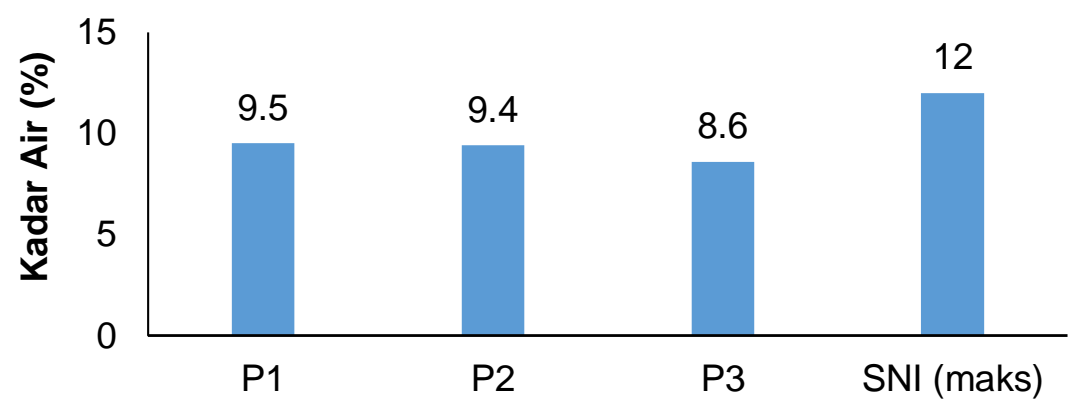

\section{Perlakuan}

Gambar 3. Perbandingan Kadar Air Pelet Bio Slurry (P1, P2, dan P3) dan Standar Nasional Indonesia 01-4087-2006.

\section{Kadar Lemak}

Berdasarkan penelitian yang telah dilakukan ketiga perlakuan memiliki kadar lemak yang sesuai dengan SNI dengan nilai maksimal 5\%. P1 memiliki kadar lemak paling besar yakni $2.16 \%$. P2 memiliki kandungan lemak yang hampir sama dengan P1 yakni sebesar $2.11 \%$. Sementara itu, P3 memiliki kandungan lemak paling rendah yakni 1.9\%. Menurut Dani dkk. (2005), adanya lemak dalam pakan berpengaruh terhadap rasa dan tekstur pakan.

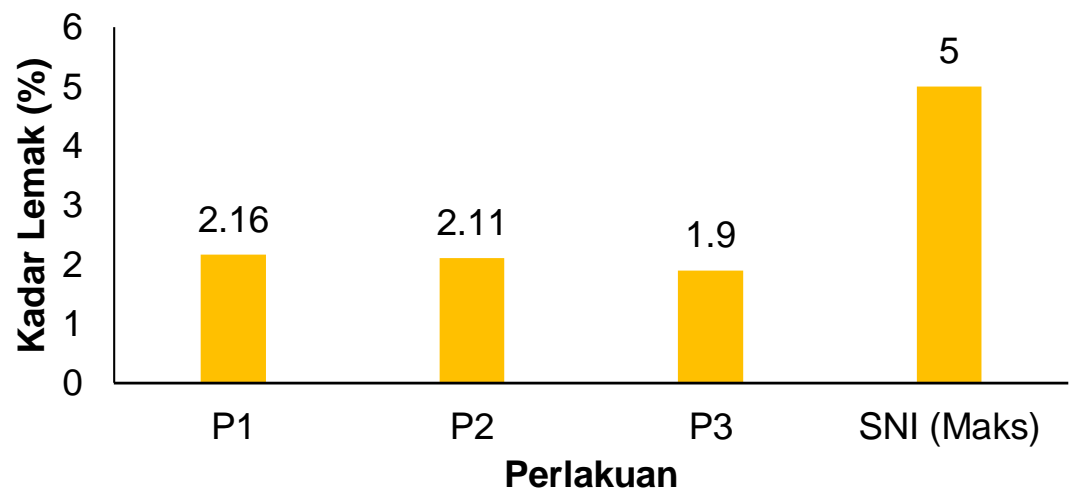

Gambar 4. Perbandingan Kadar Lemak Pelet Bio Slurry (P1, P2, dan P3) dan Standar Nasional Indonesia 01-4087-2006.

Dikatakan Mudjiman (2004), bahwa secara alami, semua energi yang dibutuhkan oleh seekor ikan berasal dari protein. Jadi, protein digunakan untuk pertumbuhan dan pemeliharaan tubuh. Di samping itu, untuk pemeliharaan tubuh dapat digunakan energi yang berasal dari lemak dan karbohidrat. Oleh karena itu, secara terbatas lemak dan karbohidrat dapat digunakan untuk menggantikan peran protein sebagai sumber energi dalam pemeliharaan tubuh. Dengan demikian protein akan lebih terarah untuk sumber energi pertumbuhan.

\section{Kadar Serat Kasar}

Serat kasar ketiga perlakuan memiliki kadar serat kasar yang tergolong tinggi. Kadar serat kasar terendah pada P1 yakni sebesar 15,5\%. Sementara itu, P2 memiliki kadar serat kasar 17\% dan P3 memiliki kadar serat kasar paling tinggi yakni 20\%. Namun, ketiga perlakuan tidak sesuai dengan SNI pelet ikan lele dumbo yakni SNI maksimal untuk serat kasar sebesar $8 \%$. Tingginya serat dalam pelet berbahan bio slurry disebabkan karena bahan bio slurry yang digunakan. Bio slurry yang berasal dari hasil fermentasi kotoran sapi mengandung tingginya serat. Menurut Nurhajati dan Suprapto (2013), serat kasar adalah 
bahan organik yang tidak larut dalam asam lemah dan basa lemah yang terdiri dari selulosa, hemiselulosa dan lignin.

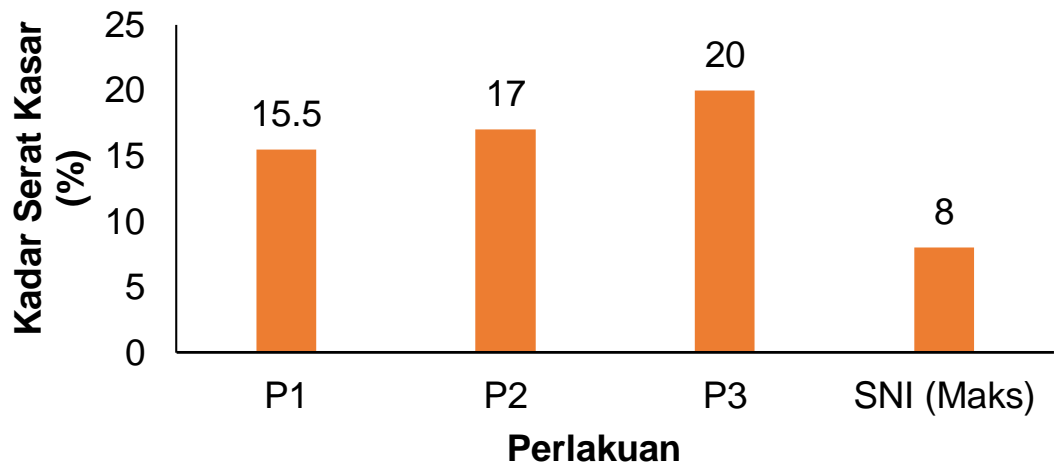

Gambar 5. Perbandingan Kadar Serat Kasar Pelet Bio Slurry (P1, P2, dan P3) dan Standar Nasional Indonesia 01-4087-2006.

\section{Daya Apung Pelet}

Berdasarkan data hasil uji coba daya apung pelet ikan dalam air tawar didapatkan data sebagai berikut: P1 memiliki daya apung paling rendah yakni selama 54.5 menit. P2 memiliki waktu apung selama 57.25 menit. P3 memiliki daya apung paling lama yakni selama 62.25 menit.

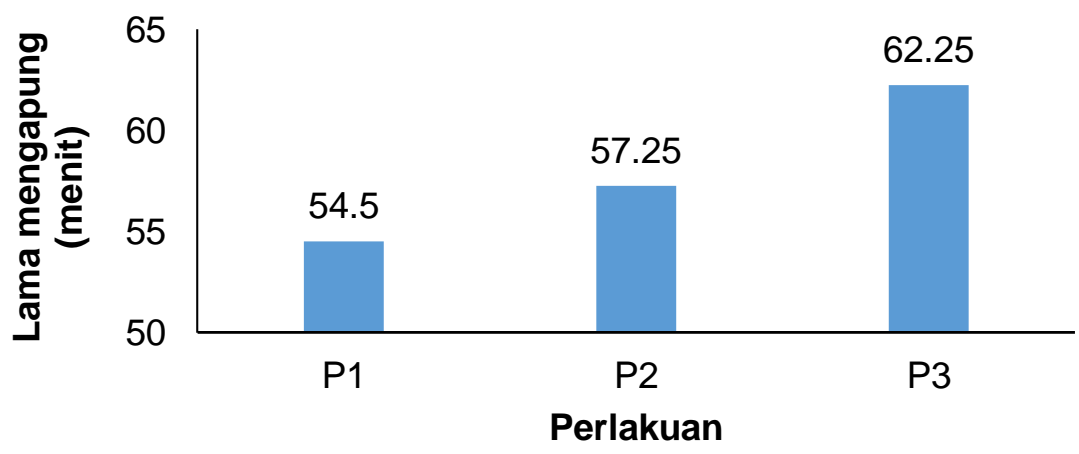

Gambar 6. Perbandingan Kemampuan Pelet Bio Slurry Mengapung Pada Ketiga Variabel P1, P2, Dan P3.

Perbedaan teknologi pembuatan pakan ikan serta ukuran partikel bahan penyusun pakan diduga berpengaruh pada daya apung. Daya apung pakan akan meningkat jika pakan diproses menggunakan alat ekstruder. Pakan ikan lele tidak membutuhkan waktu mengapung yang lama, semakin lama waktu apung pakan ikan semakin baik, namun untuk pakan ikan yang hidup didasar waktu apung bukan suatu masalah, namun yang perlu diperhatikan adalah daya tahan pakan didalam air (Romadhon dkk, 2013).

\section{SIMPULAN}

Berdasarkan penelitian yang telah dilakukan perlakuan terbaik yang diperoleh dari ketiga faktor yang ditentukan adalah $\mathrm{P} 1$ dengan dengan komposisi bio slurry $25 \%$; tepung ikan 40\%; dedak 10\%; jerohan ayam 20\%; dan tepung tapioka 5\%. P1 dipilih dengan menggunakan metode Multiple atributte Zeleny dengan memiliki hasil uji analisis proksimat yang mendekati SNI 01-4087-2006 mengenai pakan buatan untuk ikan lele dumbo (Clarias gariepinus) pada budidaya intensif. Hasil uji proksimat untuk P1 adalah kadar protein $18.93 \%$, 
kadar lemak $2.16 \%$, kadar abu $21.42 \%$, kadar serat kasar $15.50 \%$, kadar air $9.50 \%$, dan daya apung selama 54.50 menit.

\section{UCAPAN TERIMA KASIH}

Ucapan terima kasih saya ucapkan kepada warga desa Argosari Kecamatan Jabung Kabupaten Malang atas dukungan dan partisipasi untuk pelaksanaan pengabdian dan penelitian mengenai bio slurry menjadi produk pelet.

\section{DAFTAR PUSTAKA}

Dani, N.P., Budiharjo, A., dan Listyawati, S. 2005. Komposisi Pakan Buatan Untuk Meningkatkan Pertumbuhan dan Kandungan Protein Ikan Tawes (Puntius javanicus Blkr.) Jurnal BioSmart 7: 2, 83-90.

Falahudin I., Syarifah, dan Rahmalia M. 2016. Pengaruh Jenis Pakan Usus Ayam dan Tepung Ikan Terhadap Pertumbuhan Lele Dumbo (Clarias gariepinus). Jurnal Biota 2: 2, 132137.

Hariati, E. 2010. Potensi Tepung Cacing Sutera (Tubifex Sp.) dan Tepung Tapioka untuk Substitusi Pakan Komersial Ikan Patin (Pangasius hypophtalmus). Skripsi. Universitas Atma Jaya. Yogyakarta.

Marlitha, M. 2013. Pemanfaatan Limbah Roti Dalam Pakan Buatan Terhadap Pertumbuhan dan Efisiensi Pakan Benih Lele Dumbo (Clarias gariepinus). Tesis. Universitas Padjadjaran. Bandung.

Mudjiman, A. 2004. Makanan ikan. Penebar Swadaya. Jakarta. $182 \mathrm{hlm}$.

Nuraini, S. 2017. Kajian Kualitas Pakan Ikan Lele Berbentuk Pelet dengan Memanfaatkan Limbah Pertanian dan Slurry Biogas (Studi pada Kelompok Budidaya Ikan Desa Garung, Kecamatan Sambreng, Kabupaten Lamongan). Skripsi. Universitas Brawijaya. Malang.

Nurhajati, T. dan Suprapto, T. 2013. Penurunan Serat Kasar dan Peningkatan Protein Kasar Sabut Kelapa (Cocos nucifera Linn) Secara Amofer dengan Bakteri Selulolitik (Actinobacillus MI-08) dalam Pemanfaatan Limbah Pasar Sebagai Sumber Bahan Pakan. Skripsi. Universitas Airlangga. Surabaya.

Romadhon, I.K., Komar, N., dan Yulianingsih. 2013. Desain Optimal Pengolahan Sludge Padat Biogas Sebagai Bahan Baku Pelet Pakan Ikan Lele. Jurnal Bioproses Komoditas Tropis 1: 1, 26-35.

Saade, E. dan Aslamyah, S. 2009. Uji Fisik Dan Kimiawi Pakan Buatan Untuk Udang Windu (Penaeus monodon Fab.) yang Menggunakan Berbagai Jenis Rumput Laut Sebagai Bahan Perekat. Jurnal Ilmu Kelautan dan Perikanan 19: 2, 107-115.

Sahwan, F.M. 2002. Pakan Ikan dan Udang. Penebar Swadaya. Jakarta.

Susanti, N.P.R.N., Trisnadewi, A.A.A.S. dan Witariadi, N. M. 2016. Pertumbuhan Dan Produksi Hijauan Stylosanthes guianensis pada Berbagai Level Aplikasi Pupuk BioSlurry. Journal of Tropical Animal Science 4: 1, 268-284. 